\title{
Aberrant Methylation of the 16q22.1 Tumor Suppressor Gene CDH11 Promotes Tumorigenesis and Progression of Renal Cell Carcinoma through NF-kB Pathway
}

\section{Ben Xu ( $\nabla$ xuben_pku@sina.com )}

peking university first hospital https://orcid.org/0000-0002-9590-1287

\section{Hai-feng Song}

peking university first hospital

\section{Cheng Luo}

peking university first hospital

Lei Liang

peking university first hospital

Qian Zhang

peking university first hospital

\section{Keywords:}

Posted Date: August 21st, 2020

DOI: https://doi.org/10.21203/rs.3.rs-57267/v1

License: (c) (1) This work is licensed under a Creative Commons Attribution 4.0 International License.

Read Full License 


\section{Abstract}

The authors have requested that this preprint be removed from Research Square. 